\title{
Leaning Rock Site (41SM325) Lithics
}

Harry J. Shafer

Follow this and additional works at: https://scholarworks.sfasu.edu/ita

Part of the American Material Culture Commons, Archaeological Anthropology Commons, Environmental Studies Commons, Other American Studies Commons, Other Arts and Humanities Commons, Other History of Art, Architecture, and Archaeology Commons, and the United States History Commons

Tell us how this article helped you.

This Article is brought to you for free and open access by the Center for Regional Heritage Research at SFA ScholarWorks. It has been accepted for inclusion in Index of Texas Archaeology: Open Access Gray Literature from the Lone Star State by an authorized editor of SFA ScholarWorks. For more information, please contact cdsscholarworks@sfasu.edu. 
Leaning Rock Site (41SM325) Lithics

Creative Commons License

(c) $($ ) $(9)$

This work is licensed under a Creative Commons Attribution-NonCommercial 4.0 International License 


\title{
Leaning Rock Site (41SM325) Lithics
}

\author{
Harry J. Shafer
}

\section{INTRODUCTION TO THE LITHIC ANALYSIS}

The intent of the lithic analysis from the Leaning Rock site (41SM325) in Smith County, Texas, is to glean all possible information from the artifacts. Lithic studies have taken the back seat in materials analysis from sites and projects in East Texas where archaeologists focus primarily, if not exclusively, on formal tool analysis, if any analysis is done at all. Stone tools often had complex histories, and reading these histories can provide some useful, if not the only source for, insights into tool technologies, function, style, and social inferences. Stone tools were used in entirely different functional contexts than were ceramics, and provide complimentary and often unique information not provided by any other material artifact class.

The lithic analysis was conducted first to provide a descriptive report of the sample, and second to assess stylistic, chronological, functional, and behavioral information where possible. Smith County is an impoverished region in terms of lithic natural resources (Banks 1990). The materials available to the prehistoric Woodland and Caddo populations consisted mainly of orthoquartzite pebbles from extensively reworked Uvalde Pliocene gravels, small chert pebbles, silicified wood, ferruginous sandstone, and hematite. The orthoquartzite, chert, and silicified wood occur as secondary deposits in local streams. Imported chert, or rarely novaculite, can often be identified in finished artifacts such as dart points, arrow points, and finely finished biface knives (Shafer 1973:343). In the latter cases, the artifacts themselves were most likely introduced in finished form. Ground stone artifacts such as celts also were imported in finished form from Caddo populations that had access to the lithic resources found in the Ouachita Mountains of eastern Oklahoma and southwestern Arkansas (Shafer 1973:308).

Given the impoverished nature of the locally available lithic resources, one of the objectives of the debitage analysis was to plot the raw material types. Technological information was limited because of the very small and fragmentary nature of the flakes and other debitage. Despite this shortcoming, some interesting observations regarding technology were possible, such as the identification of punch-produced thinning flakes and bipolar technology. The latter may have been primarily associated with silicified wood and chert pieces used as wedges to split wood. More on this topic is presented below with the discussion of "battered pieces" or wedges.

\section{ARTIFACT DESCRIPTIONS}

The lithic artifacts were divided into material classes following standard procedures for sorting and classifying lithic assemblages. Artifacts were first sorted on the basis of overall technology (chipped stone and ground and/ or pecked stone). Chipped stone artifacts were grouped into functional and/or technological classes. Artifacts were grouped into functional and descriptive classes, although these categories could not always be logically 
followed. The groupings are: projectile points, perforators, bifaces, battered pieces or wedges, utilized flakes, and chipped adze/celt. Ground and/or pecked stone artifacts are grouped into the following categories: celt fragments, hammerstone or pecking stone, and pot polishing stones. Miscellaneous artifacts and chipping debitage are also described under separate headings.

\section{Chipped Stone}

\section{Projectile points}

The projectile points are divided into arrow points and dart points based on technology and morphology.

Arrow Points $(n=4)$

The four points are illustrated in Figure 1A-D. One untyped point (Figure 1A) has a parallel stem, rounded base, and a shouldered serrated blade. The material is a non-local gray-tan chert. The point was recovered from TU-9, 20-30 cm. Length: $16 \mathrm{~mm}$; Width: $9 \mathrm{~mm}$; Thickness: $2.5 \mathrm{~mm}$.

Another untyped point (see Figure 1B) is unifacially fashioned from gray chert; it has a short stem that contracts to a point, as well as a shouldered but not barbed blade. The point may not have been finished. The point was recovered from TU-1, 40-50 cm. Length: $19 \mathrm{~mm}$; Width: $11.5 \mathrm{~mm}$; Thickness: $3.5 \mathrm{~mm}$.

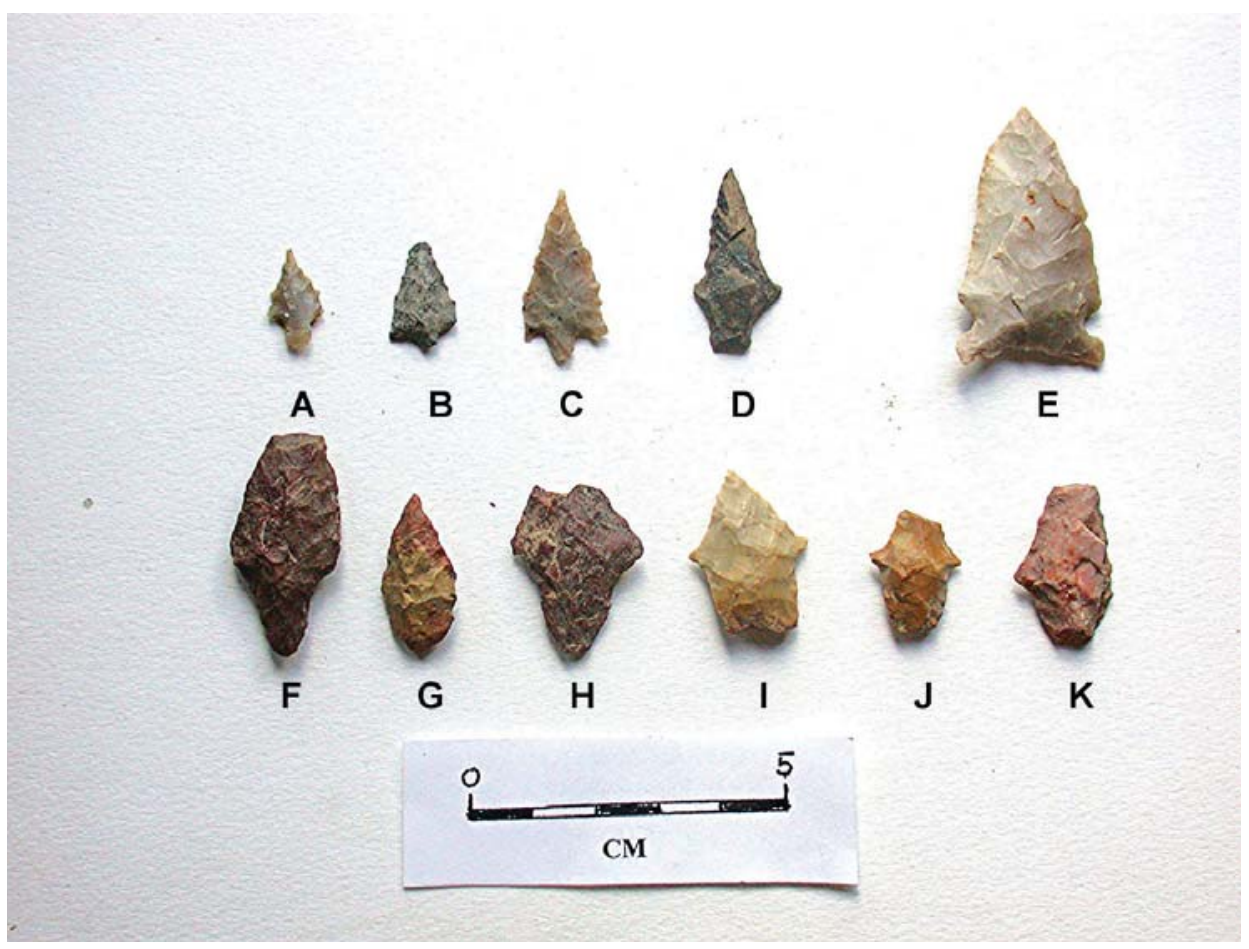

Figure 1. Projectile points. Arrow points: A-C, possible Perdiz-Bassett; D, Friley; Dart points: E, Big Sandy; F-K, Gary. 
A third untyped specimen (see Figure 1C) is of a non-local tan chert with dark brown spots. It too has a short, contracting stem with a barbed blade that is slightly serrated. The artifact was recovered from TU-13, 20-30 cm. Length: $29 \mathrm{~mm}$; Width: $14 \mathrm{~mm}$; Thickness: $3 \mathrm{~mm}$.

The fourth example (Figure 1D) conforms to the Friley type, albeit a very crude example. It has a square stem, concave blade edges below the shoulders, and a long narrow blade. The flaking is entirely unifacial. The material is silicified wood. Provenience: TU-13, 20-30 cm. Length: $29 \mathrm{~mm}$; Width: $14 \mathrm{~mm}$; Thickness: $5 \mathrm{~mm}$.

\section{Arrow Point Preform $(n=1)$}

This artifact (Figure 2A) is a failed attempt to make an arrow point from a silicified wood flake. The distal tip is bifacially formed and tapered to a point. The proximal end is largely unworked and apparently the effort was thwarted by the thickened striking platform of the flake blank. Provenience: TU-12, 20-30 cm. Length $25.5 \mathrm{~mm}$., Width: $19 \mathrm{~mm}$.; Thickness: $7 \mathrm{~mm}$.

\section{Comments on Arrow Points}

The typological assessment of the small arrow point sample from the Leaning Rock site is somewhat problematic. The Friley example is the exception, and probably predates the remaining three points. The variability represented in the remaining three points is doubtfully significant given the tiny sizes and raw material. Two are of non-local chert. All three fall into the Perdiz-Bassett genre, but I hesitate to classify them as Perdiz due

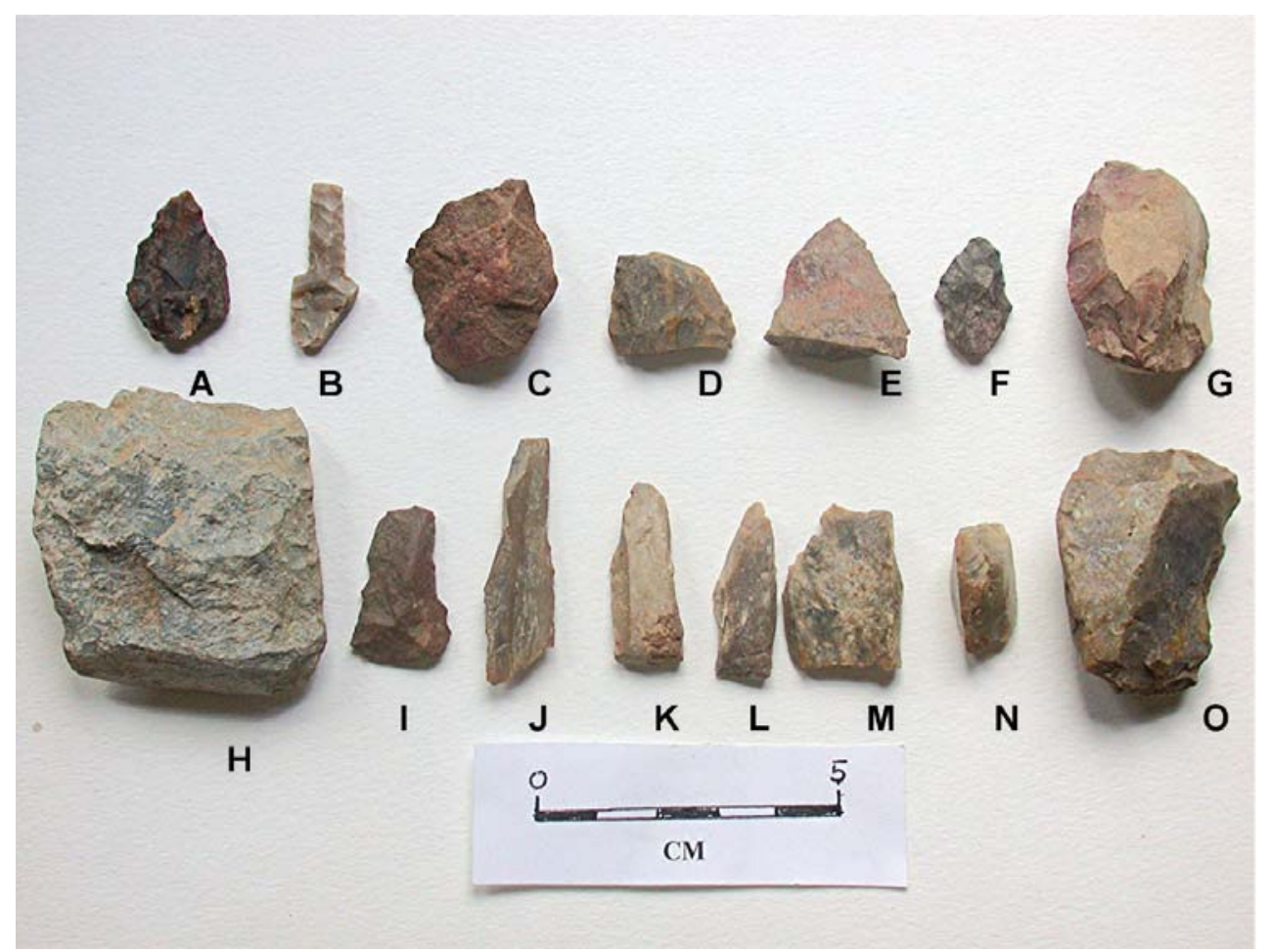

Figure 2. Other Artifacts: A, arrow point perform; B, perforator; C-G, bifaces, H, adze or celt; I-J, Utilized flakes; K-O, battered pieces or wedges. 
to the wide regional variation known for this type across the state and will use the term "Perdiz-Bassett" here to signify stylistic variability and the overlap between these two formal types. The variability seen in this small sample is consistent with larger samples of arrow points recovered from Caddo sites of comparable age such as Oak Hill Village (Rogers and Perttula 2004:167-174), and Deshazo (Girard 1995). Also, only two of the Perdiz-Bassett arrow points (see Figure 1A, C) were probably intended for use in hunting or warfare. The one small Perdiz-Bassett specimen (see Figure 1B) may very well have been a novice attempt to pattern an arrow point after those made by their male elders. The material expression of novices is something that is beyond the radar of archaeologists, but should be taken into account when material culture assemblages are analyzed.

\section{Dart Points $(n=7)$}

Seven artifacts are classed as dart points based on their morphology and technology. One is classed as a Big Sandy type (Turner and Hester 1999: 81) and the remainder fall within the Gary type (Suhm et al. 1954; Turner and Hester 1999:123-124).

\section{$\operatorname{Big} \operatorname{Sandy}(n=1)$}

This complete side-notched point of non-local light to dark tan chert exhibits a reworked tip (see Figure 1E). The reworking of the blade resulted in a slight twist to the left. The base is slightly concave and the blade edges are slight convex on one edge and re-curved on the other; the latter is the result of reworking the tip. The point was a surface find. Big Sandy is associated with Early Archaic components in East Texas (Duffield 1963: Figure 6C-F; Turner and Hester 1999:123; Webb et al. 1971:15-17).

\section{Gary (n=6)}

The Gary points are described individually and are shown in Figure 1F-K. The specimen in Figure 1F has a narrow, contracting, slightly asymmetrical stem, weak shoulders, and a triangular blade. The tip has been snapped. The material is a reddish, heat-treated orthoquartzite. Provenience: TU-9, 30-40 cm. Length: $34 \mathrm{~mm}$; Width at shoulders: $16 \mathrm{~mm}$; Thickness: $9 \mathrm{~mm}$.

The second specimen (see Figure 1G), is a very small, contracting stem point with a rounded base. The blade has been so extensively reworked as to create a shoulder-less point. This tiny point is all that remains of an extensively reworked Gary. The material is heat-treated orthoquartzite. Provenience: Block 36, Surface. Length: $25 \mathrm{~mm}$; Width: $13 \mathrm{~m}$; Thickness: $8 \mathrm{~mm}$.

The third specimen (see Figure 1H) exhibits a contracting stem that is tapered to a point, prominent shoulders, and a triangular blade. The tip is broken. The material is a deep red heat-treated orthoquartzite. Provenience: TU-12, Feature 5, 70-80 cm. Length: $26.5 \mathrm{~mm}$; Width: $21.2 \mathrm{~mm}$; Thickness: $7.5 \mathrm{~mm}$.

The fourth specimen (see Figure 1I) has a contracting stem, an un-worked base, and slight shoulders. The blade edges expand, but are convex below the shoulders (similar to Friley arrow points; see Turner and Hester 1999:214) due to extensive reworking of the blade. The material is tan chert. Provenience: Block 51, surface. Length: $26.5 \mathrm{~mm}$; Width: $19 \mathrm{~mm}$; Thickness: $7 \mathrm{~mm}$. 
The fifth Gary point (see Figure 1J) has a contracting stem, slight shoulders, and convex blade edges below the shoulders like the fourth specimen mentioned above. The blade is broken by a direct impact. The material is yellow chert. Provenience: TU-11, 30-40 cm. Length 19 mm; Width: $15 \mathrm{~mm}$; Thickness: $6 \mathrm{~mm}$.

The sixth example (see Figure $1 \mathrm{~K}$ ) is a tiny contracting stem point, with weak shoulders, and concave blade edges. It was extensively reworked and evidence of failed further attempts to thin the point can be seen in the form of step flake scars. The material is pink novaculite. Provenience: TU-11, 30-40 cm. Length: $25 \mathrm{~mm}$; Width: $16 \mathrm{~mm}$; Thickness: $9.5 \mathrm{~mm}$.

\section{Comments on Dart Points}

The six Gary points form an interesting assemblage. For one thing, they are all diminutive and exhibit the ultimate efforts of repair such that they were reduced to nubbins. Despite the extensive amount of reduction from salvaging efforts and overall morphological variability in the sample, the stems provide the attributes to identify them all as Gary. The raw material varied with heat-treated orthoquartzite being represented by three specimens, chert by two points, and novaculite by one Gary point. Small Gary points are a diagnostic artifact form for the early and middle Woodland components in East Texas (Perttula 2004:376). Their presence in this assemblage is attributed to admixture of early Woodland and Middle Caddo material within the site area.

\section{Other Chipped Stone Artifacts}

Several lithic artifacts other than projectile points were identified in the collection from the Leaning Rock site. In some respects these are more revealing in terms of function than are the points. The other lithic artifacts include a perforator, bifaces, battered pieces or wedges, utilized flakes, and a makeshift adze or celt. Debitage is described separately.

\section{Perforator $(n=1)$}

This specimen (Figure 2B) is made on a non-local chert flake. The base is mostly un-worked and the shaft is well fashioned with parallel edges. The tip is broken. Provenience: Block 37 surface. Length: 29 mm; Width: $11 \mathrm{~mm}$; Thickness: $4.5 \mathrm{~mm}$.

\section{Bifaces $(n=5)$}

The biface shown in Figure $2 \mathrm{C}$ is a heat-treated orthoquartzite piece. It is probably an aborted attempt to fashion a Gary point. Provenience: Surface. Length: $34.5 \mathrm{~mm}$; Width: $21.5 \mathrm{~mm}$; Thickness: $7 \mathrm{~mm}$.

The specimen in Figure 2D is the medial fragment of a silicified wood biface, probably a dart point. Provenience: TU-1, 10-20 cm. Length: $19 \mathrm{~mm}$; Width: $21.5 \mathrm{~mm}$; Thickness: $7 \mathrm{~mm}$.

The third example (Figure 2E) is the distal portion of an early stage orthoquartzite biface. Provenience: Block 15 surface. Length: $23 \mathrm{~mm}$; Width: $24 \mathrm{~mm}$; Thickness: $11 \mathrm{~mm}$.

The fourth biface (Figure 2F) is the burned distal portion, probably a dart point. It is a thermally discolored 
chert. Provenience: TU-11, 20-30 cm. Length: $20 \mathrm{~mm}$; Width: $17 \mathrm{~mm}$; Thickness: $4 \mathrm{~mm}$.

The very crude biface shown in Figure $2 \mathrm{G}$ is an orthoquartzite pebble exhibiting flake scars bifacially in a failed effort to thin the pebble. Provenience: TU-12, Feature 5, 80-90 cm. Length: $36 \mathrm{~mm}$; Width: $26 \mathrm{~mm}$; Thickness: $20 \mathrm{~mm}$.

\section{Battered pieces or wedges $(n=6)$}

Seven artifacts were identified as battered pieces or wedges based on the observation that they had opposed battered and/or crushed edges, or the remnants thereof. Five are illustrated in Figure 2K-O. These artifacts were subjected to bipolar battering and were most likely the end products of slivers or flakes used as wedges to split wood. When the sharp edge of a flake or nodule is placed in a slot and hit with a hammer, both impact points will display crushing or bi-polar fracture characteristics. In the case of the Leaning Rock specimens, extensive use is indicated by edge crushing, and on one example (see Figure 2O) dulling or smoothing created by repeated wear subsequent to edge fracture. Others are slivers and fragments of silicified wood that were used as wedges; damage and breakage patterns are characteristic of bipolar impact force (see Shafer 1973:112-114; Brewington et al. 1995:78-81).

Provenience: Block 39, surface, silicified wood, Length: $30 \mathrm{~mm}$; Width: $10 \mathrm{~mm}$., Thickness: $6 \mathrm{~mm}$; TU-11, 0-10 cm, Length: $20.5 \mathrm{~mm}$, Width: $15 \mathrm{~mm}$., Thickness: $11.5 \mathrm{~mm}$ ); TU-11, 10-20 cm (two specimens), recycled polishing stone, material is a orthoquartzite. Length $41 \mathrm{~mm}$., Width: $31 \mathrm{~mm}$, Thickness: $19 \mathrm{~mm}$; smaller specimen: material, chert; Length: $23 \mathrm{~mm}$, Width: $11.5 \mathrm{~mm}$, Thickness: $6 \mathrm{~mm}$; TU-12, Feature 5, 80-90 cm, silicified wood, Length: $28 \mathrm{~mm}$, Width: $23 \mathrm{~mm}$, Thickness: $8 \mathrm{~mm}$; TU-13 20-30 cm, chert, Length: $31 \mathrm{~mm}$, Width: $25 \mathrm{~mm}$, Thickness: $20 \mathrm{~mm}$.

\section{Utilized Flakes $(n=2)$}

Both are flakes that exhibit micro-flaking along one sharp edge created by pressure from use (see Figure 2 I-J). One is a chert cortex flake and the other is a sliver of silicified wood.

Provenience: Chert: TU-6, 20-30 cm. Length: $27 \mathrm{~mm}$, Width, $17 \mathrm{~mm}$, Thickness: $6 \mathrm{~mm}$; silicified wood: TU-12, 20-30 cm. Length: $41 \mathrm{~mm}$; Width: $11.5 \mathrm{~mm}$; Thickness: $6.5 \mathrm{~mm}$.

\section{Chipped Adze or Celt $(n=1)$}

This interesting make-shift adze or celt (see Figure $2 \mathrm{H}$ ) was made from the recycled fragment of a celt. Part of the ground surface of the original celt is retained on the proximal end. The give-away attributes for the adze or celt classification were the chipped and ground lateral edges and sharp, faintly beveled distal end. The lateral edge grinding was to facilitate hafting. The raw material is an imported igneous rock, possibly a porphyry. The crystalline rock is not conducive to conchoidial fracture, so the flake scares are quite ragged.

Provenience: TU-1, 20-30 cm. Length: $51 \mathrm{~mm}$; Width: $45 \mathrm{~mm}$; Thickness: $21 \mathrm{~mm}$. 


\section{Ground and/or Pecked Stone Artifacts}

Artifacts that were shaped by pecking and/or abrasion are described under this heading.

\section{Pot Polishing Stones $(n=3)$}

These artifacts are smoothed and highly polished pebbles. Scratches and striations seen under 10X magnification attest to the fact that they are indeed artifacts and not natural gravels. One complete example (Figure 3A) is a natural pebble that was extensively used to the point that a dull polish can be seen on most of its surface; the polish is especially prominent on the flatter surface. The second example (Figure 3B) is made of a red jasper (possibly made red from heat). This polishing stone is damaged from thermal fracture, but the surfaces are very highly polished with visible scratches and striations. The third specimen is a fine-grained quartzite pebble polished around much of its circumference. There is little question as to how these three artifacts were used.

Provenience: TU-11, 10-20 cm.; Material: Orthoquartzite?; Length: 49 mm, Width: 35 mm; Thickness: 30 mm; TU-12, 20-30 cm. Material: jasper; Length: 37 mm; Width: 14 mm; Thickness: 14 mm; TU-11, Feature 3, \#1, $51 \mathrm{~cm}$ bs. Material: fine-grained quartzite.

\section{Comments}

Caddo ceramic technology includes the use of polishing stones during the process of burnishing while the ceramic body is leather hard. Stones used for polishing vessels achieve a very polished surface from abrasion with the gritty clays. Pot polishing stones were often curated and handed down from generation to generation among Native American potters (Rose Gonzales, San Ildefonso Pueblo, personal communication 1974),

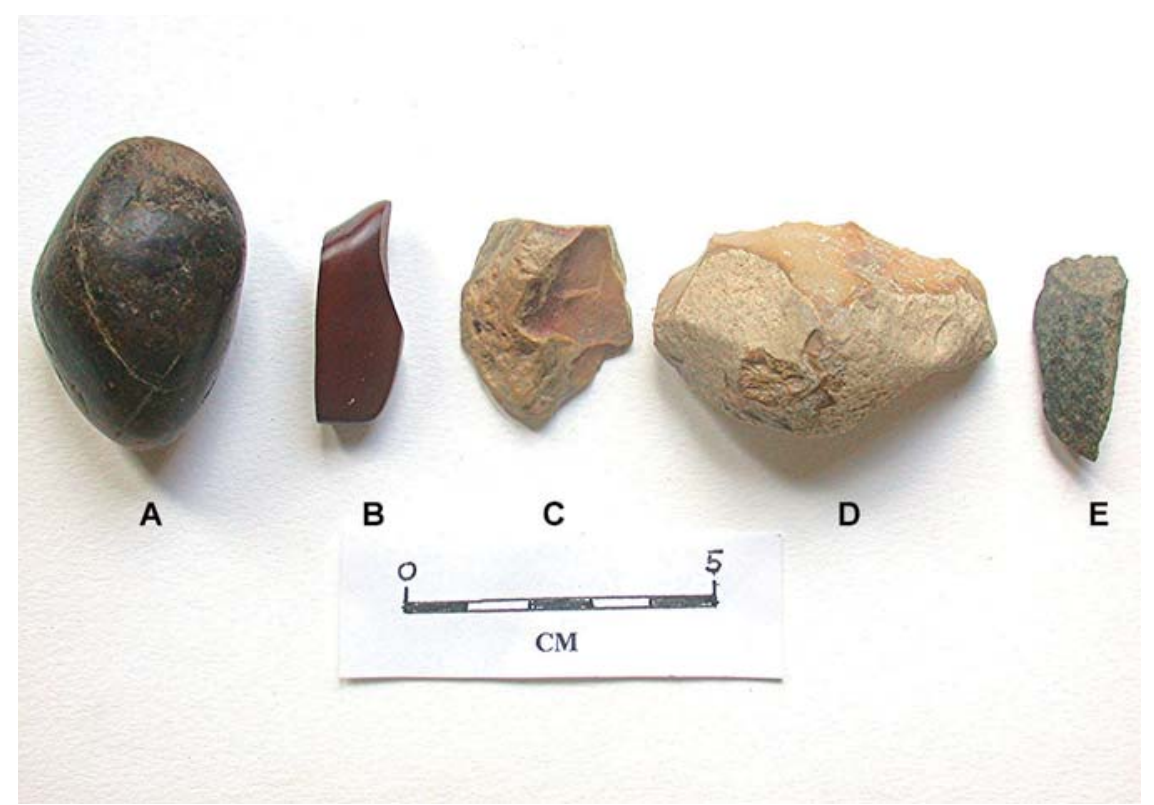

Figure 3. Polishing stones, cores, and spall from a celt: A-B, polishing stones;

C-D, cores; E, spall from Ouachita Sandstone celt. 
and pot polishing stones were often included in ancient Caddo tombs (Shafer 1973:319-323) and in potter's graves elsewhere (Shafer 1973: 310-323, 1985). The presence of polishing stones in this assemblage provides circumstantial evidence that potters were at work at this site.

\section{Celt Debitage $(n=4)$}

Four flakes (one shown in Figure 3E and another in Figure 4A) were removed from quartzitic sandstone celts, either due to recycling the celt material or from the shattering of the celts. One (Figure 4A) is a long spall removed from near the distal end of a celt, perhaps by impact. It was recovered from Feature $3,21 \mathrm{~cm} \mathrm{bs}$. The fragment measures $90 \mathrm{~mm}$ long, $34 \mathrm{~mm}$ wide, and $10 \mathrm{~mm}$ thick. Another was recovered from TU-10, 10-20 $\mathrm{cm}$. A third came from TU-12, 10-20 cm, and a fourth from TU-3, 0-10 cm.

\section{Celt fragments $(n=4)$}

In addition to the four pieces of debitage from celt recycling described above, four fragments representing three celts were recovered in the testing at the Leaning Rock site.

One specimen (see Figure 4B) is the poll end of a celt that was snapped and shattered. Since the fracture occurred in the haft zone, it was probably broken by impact. Provenience: TU-13, 20-30 cm. It measures $62 \mathrm{~mm}$ long, $38 \mathrm{~mm}$ wide, and $26 \mathrm{~mm}$ thick.

The second celt fragment (see Figure 4C) consists of two fragments that conjoin. They comprise the poll end of a celt shattered by burning. One was recovered from TU-5, 0-10 cm and the other from TU-10, 40-50 cm. The differences in depth and distance from the two fragments may suggest serious bioturbation in the deposits. Together the fragments measure $43 \mathrm{~mm}$ long, $32 \mathrm{~mm}$ wide, and $29 \mathrm{~mm}$ thick.

A third fragment (see Figure 4D) is a medial fragment of a shattered celt recovered from the surface of Block 57. It measures $45 \mathrm{~mm}$ long, $40 \mathrm{~mm}$ wide, and $15 \mathrm{~mm}$ thick.

All of the celt fragments and debitage from celt recycling are of a similar imported quartzitic sandstone, a common material in Caddo celt manufacture. The material has been noted in outcrops throughout the Ouachita Mountains and according to Banks and Winters (1975:27), it is either from the Stanley Shale or Jackfork Formation. Although the debitage sample contains three items of dark green quartzitic sandstone removed from celt fragments (coded Oss in Table 1, see below), there is no evidence that celts were manufactured from blanks brought to the site. The general pattern throughout the Caddoan area in Texas is that completed celts of exotic material were imported into the area (see Banks and Winters 1975: 35; Shafer 1973:299-309).

\section{Hammerstone/Pecking stone (n=1).}

This interesting artifact (see Figure 4E) was made from a recycled dark green quartzitic sandstone celt fragment. It is sub-rounded with a bifacially tapered end that does not come to a point. The surface is highly pecked, suggesting intentional shaping. It may have been a hammerstone or a pecking stone, but its real function or functions is unknown.

Provenience: TU-11, 20-30 cm. Length: $44 \mathrm{~mm}$; Width, $42.5 \mathrm{~mm}$; Thickness: $33 \mathrm{~mm}$. 


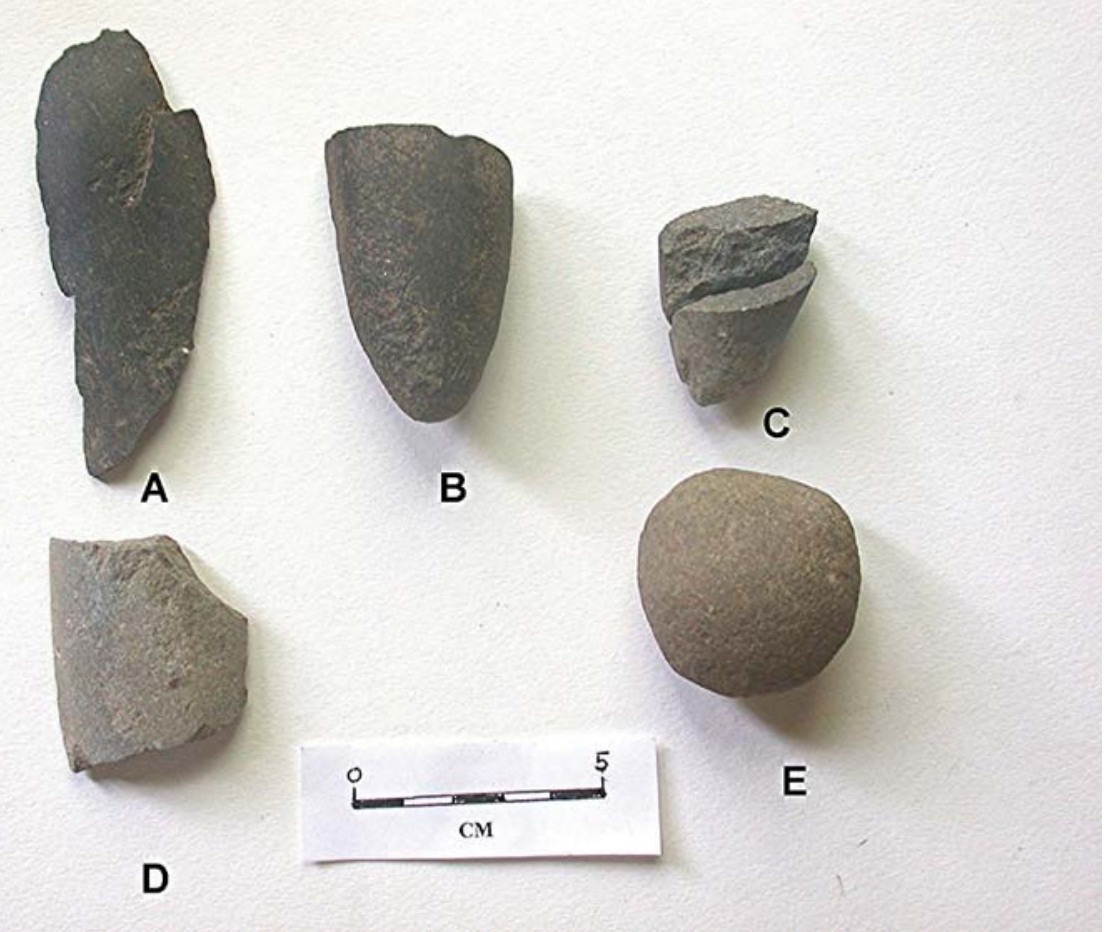

Figure 4. Celt fragments and hammerstone/pecking stone: A, spall from celt; B-C, poll end of celts; D, medial fragment of a celt; E, hammerstone/pecking stone made from a recycled celt fragment.

\section{Chipping Debitage and Miscellaneous Artifacts}

\section{Chipping Debitage $(n=161)$}

Chipping waste consists of cores and flakes, the residue from chipped stone manufacture and retouch. The general paucity of local raw material and the need for several classes of chipped stone tools made raw material a prime resource. As a result, masses of material were extensively reduced to very small sizes, and any broken tool, such as celts and pot polishing stones, were recycled for the raw material and put to use.

Three categories of raw material dominated the sample, silicified wood, orthoquartzite, and chert, occurring in about equal percentage. Both silicified wood (54 specimens, or 33.5\%) and chert occurred in equal proportions while orthoquartzite (50 specimens or $31 \%$ ) was slightly less. Quartzitic sandstone, a product of recycling raw material from broken celts, accounted for the remaining three specimens (2\%). Also, it should be noted that the size of the debitage was very small (although not measured), probably the product of reducing pebbles rather than larger masses of material. The small size of the debitage and the categories represented are consistent with exploitation of locally available resources rather than importing raw material. 
Table 1. Leaning Rock Site (41SM325) Debitage.

$\begin{array}{lllllllllll}\text { Unit/Material } & \text { lv. } 1 & \text { lv. } 2 & \text { lv. } 3 & \text { lv. } 4 & \text { lv. } 5 & \text { lv. } 6 & \text { lv. } 7 & \begin{array}{l}70-75 \\ \mathrm{~cm}\end{array} & \begin{array}{l}75+ \\ \mathrm{cm}\end{array} & \text { N }\end{array}$

\begin{tabular}{|c|c|c|c|c|c|c|c|c|c|c|}
\hline$\overline{\text { TU } 1}$ & & & & & & & & & & \\
\hline $\mathrm{Sw}^{*}$ & 1 & 1 & 4 & - & - & 1 & 1 & - & - & 8 \\
\hline $\mathrm{Oqz}$ & - & - & - & - & - & - & - & 1 & - & 1 \\
\hline $\mathrm{Ch}$ & 1 & 1 & 1 & - & 1 & - & - & - & - & 4 \\
\hline \multicolumn{11}{|l|}{ TU 2} \\
\hline $\mathrm{Sw}$ & 1 & - & - & - & - & - & - & - & - & 1 \\
\hline $\mathrm{Oqz}$ & 1 & - & 1 & - & - & - & - & - & - & 2 \\
\hline $\mathrm{Ch}$ & 1 & - & - & - & - & - & - & - & - & 1 \\
\hline \multicolumn{11}{|l|}{ TU 3} \\
\hline Sw & - & 1 & 1 & - & 1 & - & - & - & - & 3 \\
\hline $\mathrm{Oqz}$ & 1 & 1 & 1 & - & - & - & - & - & - & 3 \\
\hline $\mathrm{Ch}$ & - & - & - & - & - & - & - & - & - & 0 \\
\hline Oss & 1 & - & - & - & - & - & - & - & - & 1 \\
\hline \multicolumn{11}{|l|}{ TU 4} \\
\hline Sw & - & - & - & - & - & - & - & - & - & 0 \\
\hline $\mathrm{Oqz}$ & - & 1 & 2 & - & 1 & - & - & - & - & 4 \\
\hline Ch & 1 & - & - & - & - & - & - & - & - & 1 \\
\hline \multicolumn{11}{|c|}{ TU 5} \\
\hline Sw & - & - & - & - & - & - & - & - & - & 0 \\
\hline $\mathrm{Oqz}$ & - & 2 & - & 1 & - & - & - & - & - & 3 \\
\hline $\mathrm{Ch}$ & 1 & 1 & 1 & - & - & - & - & - & - & 3 \\
\hline \multicolumn{11}{|l|}{ TU 6} \\
\hline Sw & - & - & - & 1 & - & - & - & - & - & 1 \\
\hline $\mathrm{Oqz}$ & - & 3 & 1 & 1 & - & - & - & - & - & 5 \\
\hline $\mathrm{Ch}$ & - & - & 1 & 1 & - & - & - & - & - & 2 \\
\hline \multicolumn{11}{|l|}{ TU 7} \\
\hline Sw & 1 & 1 & 1 & - & - & - & - & - & - & 3 \\
\hline $\mathrm{Oqz}$ & - & 1 & - & 4 & - & - & - & - & - & 5 \\
\hline $\mathrm{Ch}$ & - & - & - & 1 & - & - & - & - & - & 1 \\
\hline \multicolumn{11}{|l|}{ TU 8} \\
\hline $\mathrm{Sw}$ & 1 & - & 1 & - & - & - & - & - & - & 2 \\
\hline $\mathrm{Oqz}$ & - & - & - & 1 & - & - & - & - & - & 1 \\
\hline $\mathrm{Ch}$ & 1 & - & - & - & - & - & - & - & - & 1 \\
\hline \multicolumn{11}{|l|}{ TU 9} \\
\hline $\mathrm{Sw}$ & - & 1 & 2 & - & - & - & - & - & - & 3 \\
\hline $\mathrm{Oqz}$ & - & 2 & 1 & 1 & - & - & - & - & - & 4 \\
\hline $\mathrm{Ch}$ & - & 2 & 6 & - & - & - & - & - & - & 8 \\
\hline \multicolumn{11}{|c|}{ TU 10} \\
\hline $\mathrm{Sw}$ & - & - & 3 & - & 2 & - & - & - & - & 5 \\
\hline $\mathrm{Oqz}$ & - & - & 1 & 3 & - & - & - & - & - & 4 \\
\hline $\mathrm{Ch}$ & 1 & 2 & 2 & - & - & - & - & - & - & 5 \\
\hline
\end{tabular}




\begin{tabular}{|c|c|c|c|c|c|c|c|c|c|c|}
\hline Oss & - & 1 & - & - & - & - & - & - & - & 1 \\
\hline \multicolumn{11}{|l|}{ TU 11} \\
\hline Sw & 1 & 3 & 3 & 2 & - & - & - & - & - & 9 \\
\hline $\mathrm{Oqz}$ & 1 & 2 & - & - & - & - & - & - & - & 3 \\
\hline $\mathrm{Ch}$ & 1 & 1 & 1 & 1 & - & - & - & - & - & 4 \\
\hline \multicolumn{11}{|l|}{ TU 12} \\
\hline Sw & - & 3 & 5 & - & - & - & - & - & - & 8 \\
\hline $\mathrm{Oqz}$ & - & 3 & 3 & - & 1 & - & - & - & - & 7 \\
\hline $\mathrm{Ch}$ & 3 & 5 & 3 & 2 & 1 & - & - & - & - & 14 \\
\hline Oss & - & 1 & - & - & - & - & - & - & - & 1 \\
\hline \multicolumn{11}{|l|}{ TU 13} \\
\hline Sw & - & 3 & 2 & 3 & - & - & - & - & - & 8 \\
\hline $\mathrm{Oqz}$ & - & 1 & 4 & - & - & - & - & - & - & 5 \\
\hline $\mathrm{Ch}$ & - & 2 & 4 & 1 & - & - & - & - & - & 7 \\
\hline \multicolumn{11}{|c|}{ Feature 3} \\
\hline $\mathrm{Oqz}$ & - & - & - & - & - & 1 & - & - & - & 1 \\
\hline \multicolumn{11}{|c|}{ Feature 5} \\
\hline Sw & - & - & - & - & - & - & 2 & 1 & - & 3 \\
\hline $\mathrm{Oqz}$ & - & - & - & - & - & - & - & 1 & 1 & 2 \\
\hline $\mathrm{Ch}$ & - & - & - & - & - & - & - & 2 & 1 & 3 \\
\hline Totals & 19 & 45 & 55 & 23 & 7 & 2 & 3 & 5 & 2 & 161 \\
\hline
\end{tabular}

*Sw-silicifed wood; Oqz=orthoquartzite; $\mathrm{Ch}=$ chert; $\mathrm{OSS}=$ Ouachita sandstone or quartzitic sandstone

Only two cores were in the sample, and both were small pebbles that exhibited two or more tiny flake removals (see Figure 3C-D). Flakes, chips, and other fragments constitute the remainder of the debitage sample. Table 1 provides a listing of these flakes by material and provenience.

No effort was made to systematically sort the flakes with striking platforms according to method of detachment, although two separate reduction methods were recognized in the sample: pressure flakes, and small arched lipped flakes removed by indirect percussion or punches. The latter is a reduction method rarely discussed in Texas archaeology, but is very likely the method used to biface the heat-treated orthoquartzite used in the manufacture of Gary points over much of the East Texas region. No other method such as pressure flaking or use of a billet seems feasible given the small size of raw material, tough material, and naturally occurring thick pebbles and cobbles.

\section{Burned ferruginous sandstone (n=1)}

One fragment of burned ferruginous sandstone is in the sample. The fragment has a curved surface that suspiciously looks like it may have come from a celt, but upon close examination revealed surface irregularities inconsistent with those of celt manufacture. If this fragment came from an artifact, the type of artifact is unknown.

Provenience: TU-12, $40-50 \mathrm{~cm}$. 


\section{SUMMARY AND DISCUSSION}

\section{Chronological and Stylistic Implications of the sample}

The lithic sample from the Leaning Rock site (41SM325) indicates a multi-component occupation. Diagnostic point types were Big Sandy, Gary, Perdiz-Bassett, and Friley. The most prominent components are a Woodland assemblage identified by Gary dart points and a Middle Caddo assemblage marked by arrow point types Perdiz/Bassett. A single Friley point may hint of a very brief Early Caddo presence at the site as well. Little emphasis is placed on the Big Sandy point since such items could have been picked up and brought to the site by Woodland or Caddo occupants (Shafer 1973:181-187).

The small sample of projectile points provides some limited stylistic information that is substantiated at other Middle Caddo sites (Rogers and Perttula 2004:167-174). The small sample of dart points also indicates the site was probably a short-term encampment for a small Late Archaic or Woodland group. The sample is dominated by Gary points; this point type can be found on virtually every hill or knoll in proximity to water throughout East Texas, and an admixture of Late Archaic/Early Woodland components can almost always be expected at most Caddo sites. The bow and arrow replacement of the atlatl spear probably took place during the MiddleLate Woodland transition at ca. A.D. 600-800, and may have defined the Late Woodland phase along with changes in ceramic styles (Perttula 2004:376). Projectile points recovered from mortuary contexts provide the best chronological evidence for the chronological separation of dart points and arrow points, however, and very strong evidence that the two did not co-occur is in early Caddo material culture at the George C. Davis site (41CE19). No dart points were recovered from any of the Mound C tombs that yielded over 200 arrow points from multiple clusters and concentrations (Shafer 1973:181-219).

The Big Sandy point would suggest either a thin Early Archaic component was represented at Leaning Rock, or the artifact was picked up and introduced in the site by the Caddo or Late Archaic-Early Woodland groups. Collecting from earlier sites was not uncommon among the Caddo (Shafer 1973:181-187). The admixture of dart points and arrow points at the Leaning Rock site deposits is attributed to mixing due to the nature of the relatively shallow and bioturbated deposits.

\section{Spatial Implications of the sample}

Small spatial samples can often result in false patterning. The caveat notwithstanding, the distribution across the excavated area of the lithic material at Leaning Rock (41SM325) does suggest that a concentrated midden deposit, and possibly a structure, was present within the area sampled in the archaeological investigations. A full analysis of the spatial distribution will need to incorporate all of the material culture, including ceramics and faunal material.

\section{Functional Implications of the sample}

Weapons for hunting and warfare were obviously maintained by all occupants of the Leaning Rock site as indi- 
cated by the presence of projectile points. Woodworking implements are well represented by the bipolar wedges or battered pieces, the small makeshift adze or celt, and celt fragments. Utilized flakes were surprisingly rare, and their rarity may be attributed to the paucity of suitable raw material, and to the historically known fact that the Caddo used the sharp edges of highly silicate native cane as knives.

An interesting discovery in the sample was pot polishing stones. These highly polished and striated pebbles were the products of polishing or burnishing the surfaces of leather-hard ceramics. Their presence in the sample stands as circumstantial evidence that some of the ceramics at the site were locally produced. Future instrumental neutron activation analysis of the ceramics could substantiate the possibility of local production. These tools do not provide useful chronological information because they are associated with ceramic technology, and may occur with any ceramic component.

Finally, the lithic artifact sample from the Leaning Rock site provides some possibly significant, if not vague, hints of resource utilization through time. The resource utilization probably relates to relative degrees of mobility or sedentary lifestyles. For example, the single Big Sandy point is a high quality chert, probably of Edwards formation origin (Banks 1990: 59-62). The Big Sandy is an Early Archaic point style associated with groups who practiced highly mobile lifestyles. The Gary points, arrow points, and debitage, on the other hand, are of materials regarded here as locally available in Northeast Texas, including orthoquartzites, small chert pebbles, and silicified wood (Girard 1995; Studer 1982). Gary points are regarded here as being associated with Woodland period occupations; Woodland groups were probably seasonally mobile, with more restricted mobility compared to the Early Archaic groups. Caddo groups were probably even more restricted in their movements compared to the Woodland groups. With trends toward reduced mobility through time, archeologists might expect more intensive uses of local as opposed to non-local resources, and the importation of non-local resources occurring mostly in the form of finished items (see Shafer 1973:337-364).

\section{REFERENCES CITED}

Banks, L. D.

1990 From Mountain Peaks to Alligator Stomachs. Memoir No. 4. Oklahoma Anthropological Society, Norman.

Banks, L. D. and J. Winters

1975 The Bentsen-Clark Site, Red River County, Texas: A Preliminary Report. Special Publication No. 2. Texas Archeological Society, San Antonio.

Brewington, R. L., J. E. Dockall, and H. J. Shafer

1995 Archaeology of 41MX5: A Late Prehistoric Caddoan Hamlet in Morris County, Texas. Reports of Investigations No. 1. Center for Environmental Archaeology, Texas A\&M University, College Station.

Duffield, L. F.

1963 The Wolfshead Site: An Archaic-Neo-American Site in San Augustine County, Texas. Bulletin of the Texas Archeological Society 34:83-141.

Girard, J. S.

1995 The Chipped Stone Collection: Technological, Functional, and Typological Analysis. In The Deshazo Site, Nacogdoches County, Texas, Vol. 2: Artifacts of Native Manufacture, edited by D. A. Story, pp. 33-156. Studies in Archeology 21. Texas Archeological Research Laboratory, The University of Texas at Austin.

Perttula, T. K.

2004 The Prehistoric and Caddoan Archeology of the Northeastern Texas Pineywoods. In The Prehistory of Texas, edited by T. K. Perttula, pp. 370-407. Texas A\&M University Press, College Station. 
Rogers, R. and T. K. Perttula

2004 The Oak Hill Village Site (41RK214), Rusk County, Texas. PBS\&J, Austin.

Shafer, H. J.

1973 Lithic Technology at the George C. Davis Site, Cherokee County, Texas. Ph.D. dissertation, Department of Anthropology, The University of Texas at Austin.

1985 A Mimbres Potter's Grave: An Example of Mimbres Craft Specialization? Bulletin of the Texas Archeological Society 56:185-200.

Studer, J. M.

1982 Archaic Pebble Core Reduction Technology in East Texas: The Icy Eye Example. Papers in Anthropology No. 3. Stephen F. Austin State University, Nacogdoches.

Suhm, D. A., A. D. Krieger, and E. B. Jelks

1954 An Introductory Handbook of Texas Archaeology. Bulletin of the Texas Archeological Society 25 (whole volume).

Turner E. S. and T. R. Hester

1999 A Field Guide to the Stone Artifacts of Texas Indians. Gulf Publishing Co., Houston.

Webb, C. B., J. L. Shiner, and E. W. Roberts

1971 The John Pearce Site (16CD56): A San Patrice Site in Caddo Parish, Louisiana. Bulletin of the Texas Archeological Society 42:1-49. 